\title{
Max Brod as a Music Critic ${ }^{1}$
}

\author{
Michał Jaczyński
}

Max Brod started his career as a music critic just before the end of the First World War after his brilliant press campaign with regard to the Jenufa - an opera by Leoš Janáček whose Viennese premiere took place in the Hofoper on 16 February 1918. ${ }^{2}$ According to the Brod's articles and reviews concerning Janáček and his work - which were first published in many German-language newspapers (e.g., Die Zeit, Schaubühne, ${ }^{3}$ Der Auftakt) and then reprinted in the Sternenhimmel, a collected volume of music and theatre reviews published in Prague in 1923 - Jenufa was almost a wonder of the Czech national opera. Brod claimed that Jenufa had been forgotten and underestimated since its Prague premiere (1916) simply because the war had upset the Czech society so much that it had become unable to appreciate the new masterpiece of national art. ${ }^{4}$ Moreover, he regarded listening to Jenufa as one of few uplifting moments (glückliches Ereignis) during the war and allowing him to feel the joy of life again. ${ }^{5}$ Subsequently, he made "the case of Janáček" a personal struggle: his later remarks on the composer and his music are highly emotional and characteristically subjective.

Those enthusiastic remarks sparked protests. For some part of the Viennese press running a premiere in 1918 was impolitic as it did not take into account the existing tension between the Germans and Czechs. It was said that the authorities of the Hofoper, facing the inevitable fall of the Austro-Hungarian monarchy, had wanted to be politically

1 This paper resulted from the source query which involved the collection of reviews and critical articles by Max Brod Sternenhimmel. Musik- und Theaterrlebnisse (Prag: Orbis; München: Kurt Wolff, 1923), and archival resources of the "Prager Tagblatt" available on the website www.aano.onb (the years' issues 1935 and 1939 were unavailable).

2 Brod translated many librettos of Czech operas into German. Jenufa staged in the Hofoper was the first of them.

3 After 1918 that renowned Berliner periodical changed its title to "Weltbühne".

4 Cf. Illustriertes Oesterreichsches Journal, April 10, 1918.

5 Max Brod, “Leoš Janáček’s Jenufa (1916),” in Sternenhimmel. 
correct to its bitter end, and thereby had included the Czech opera in the repertoire to prevent the national stage from "denationalisation" (entnazionalisiert). ${ }^{6}$ As a result, Brod was criticized for using turgid language and for the groundless enthusiasm. ${ }^{7} \mathrm{He}$ was also alleged to be self-seeking i.e. to promote the results of his own work as a translator of the libretto into German, which was strongly supported by the fact that Janáček himself, in a press interview, regarded Brod's translation as a literary masterpiece being far from a conventional libretto and taking into account all the nuances (Schattierungen) present in his music. ${ }^{8}$ In response to Brod's remarks Richard Batka, a leading German-language music critic in Prague, wrote in the "Fremdenblatt": 9

The naturalistic music by Janáček is hardly interesting and many Czechs of equal musical talent have never deserved to have their works performed in the Court Opera. Janáček is barely a musical genius.

A columnist from the Ilustriertes Oesterreichisches Journal suggested Brod "to be more objective". ${ }^{10}$ Only Julius Korngold, a prominent critic of the Neue Freie Presse, did not show a dislike for Janáček and Brod. Hence, he described the composer in a manner which was visibly influenced by Brod's opinions and his translation of the libretto:

Unpredictable brain, he has struggled with everybody for his beliefs, which raised conflicts.

Therefore he is a Mahler-like figure. ${ }^{11}$

The remarks by Korngold and Brod are parallel as both critics rendered Janáček as "unpredictable" and both refer to Mahler who - according to Brod - was a unique and unprecedented artist, an apostle of an illustrious idea (such as Janáček). Brod didn’t hesitate to call Mahler and Janáček genius composers because of their specific position within the Central European musical culture. He considered them treasurers of the idea of national art: art inseparably rooted in its cultural background. Brod thought that Mahler and Janáček had been honest and uncompromising in accepting their own "individuality" or "distinctness" i.e. in deliberate shaping their artistic self without referring to the current trends in the European art.

It is obvious that such an interpretation of the artistic attitude by Mahler and Janáček was influenced by Zionism. In 1912 Brod met Martin Buber. Since then he has considered

6 Cf. "Theater und Kunst Nachrichten,” Neue Freie Presse, January 30, 1918, 10.

7 Cf. Deutsches Volksblatt, February 13, 1918, 6; Karl Schreder, “Jenufa,” Fremdenblatt, February $17,1918$.

8 “Gespräch mit Leos Janacek,” Neues Wiener Journal, February 15, 1918, 4.

9 "Ein Genie, freilich, erscheint er uns nicht". Richard Batka, "Feuilleton. Jenufa," Fremdenblatt, February 17, 1918, 2.

10 "Distanz bekommen müssen wir!". Hans Liebrtäglch, "Jenufa," Ilustriertes Oesterreichisches Journal, No. 41 (1918): 2.

11 Julius Korngold, “Feuilleton. Hofoperntheater,” Neue Freie Presse, February 17, 1918, 1. 
Zionist ideology as a starting point towards a perfect form of life. That form would be, of course, religious - in accordance with the Chassidic maxim "serving God with joy" ("Gott mit Freude zu dienen"). ${ }^{12}$ Consequently, the art would strive to reflect that spiritual community. In a gloss to his monograph about Franz Kafka Brod wrote:

A man belonging to a nation bereft of its fatherland cannot live in dignity. ${ }^{13}$

It is a typical example of his affirmation of the art interrelated with the life-nation being a source of morality and strength and a community based on faith.

The descriptions of Janáček made by Brod between 1918 and 1923 are primarily anthropologic: in order to uncover the secret of the unique art by the Czech composer, music critic has shown him as private man in his own environment. Hence, provincial Brno from the article $A$ Journey to Janáček (Die Reise zu Janáček) ${ }^{14}$ was depicted as a perfect background for a composer being geographically and psychologically isolated from the contemporary world with its commercialization and omnipresent politics. In Brod's eyes, Janáček was an optimist who used to consider the life and himself simpleheartedly or even naively. His faith, joy typical of children, and sense of humor full of understanding would made him "young sage" who despite many fails has never become bitter and who has retained unbroken and vigorous power of creation - another proof that God every day carries out his plan regarding illustrious men.

To explain the metaphysical aspect of Janáček's art Brod referred to the figure of composer Kreisler by E. T. A Hoffman. According to him, Janáček and Kreisler "do not know how they compose" ${ }^{15}$ and the results are outstanding. Janáček creates his musical universe with the simplest means and subsequently it is far from standards typical of the contemporary music, including the clichés of the "official" national music. Brod prefers Jenufa to the operas by Smetana and Dvoŕák because the former is not a mere facade for national myths but a universal story about human nature and timeless values:

...it is a human opera. Its setting - among Moravian peasants. A drama of supreme love, of the greatest sacrifice for the posterity. A drama of delicate conscience which is deaden for a moment but then falls into the guilt and in the end openly confesses to the whole world [...] The final scene show the essence of fiery love than philosophical essays and allows the pure humanity to burst from the folklore if the latter is properly approached, without egoism. For me that music unveils what is "nation" and "nationalism" better than all other theories. ${ }^{16}$

12 Cf. "Martin Buber 50 Jahre alt," Pager Tagblatt, February 8, 1929, 6.

13 Max Brod, Franz Kafka, trans. Tadeusz Zabłudowski (Warszawa: Czytelnik, 1982), 231.

14 Max Brod, "Die Reise zu Janáček," in Sternenhimmel, 42-50.

15 Ibidem, 46, idem, Chorkonzert, Ibidem, 52.

16 ,...eine menschliche Oper, die unter mahrischen Bauern spielt. Ein Drama höchster Liebe, höchster Aufopferung, für den Nächsten!. Ein Drama des zarten Gewissens und des einen Augenblick lang getaubten Gewissens, das in Schuld gerät und zum Schluss vor der ganzen Welt offentlich seine 
For Brod a perfect national opera should contain "humanity instead of 'the opera' with its theatrical hatred". ${ }^{17}$ Therefore, he stressed the fact that Janáček's approach to the opera was independent on the current artistic conventions and thus "timeless" (Zeitlossigkeit), "eternal" (Ewigkeit) and "pristine" (Urschöpfung). ${ }^{18}$ The last of those features would reflect the inseparable bond between Janáček's music and his folk background: "Each of his modulations and motifs comprises that intimate and never exaggerated folk tradition". ${ }^{19}$

Discussing the particular musical elements and solutions in Jenufa, Brod compared that opera with the works by Wagner, Verdi, Debussy or even Bach in order to uncover the uniqueness of the style and techniques used by Janáček. His most valuable remarks regard, of course, the Janáček's theory of speech melodies (nápěvky mluvy) and how it shapes the melody and harmony in his musical works. More importantly, Brod did not share the opinion - common among music critics - that Janáček’s method was simply an example of naturalism:

The realism of that unique method may seem to be suspicious. But that's why it is so extraordinary. Here the melody does not follow the speech, yet is the tool that suggests and shapes the words. Janáček himself told how he used to derive harmony: "A motif closely intertwined with a word reflects its own heat, shines in its own light. I cut its melody and rhythm as facets of a gemstone". ${ }^{20}$

Brod took note of the fact that Janáček conducted the orchestra in a different manner than Wagner because in his operas "the core of the music" (Hauptmusik) resonates from the stage, as in the past; Brod compared a cantilena by the Czech composer to the cantilena by Verdi, but according to him the former was devoid of eclecticism as the genius of Janáček created real voices of nature (Naturlaute) - vigorous and firm melodies which resemble genuine Moravian folksongs. After depicting the impact of expressionism and impressionism on Janáček's music (the issue of staticness), Brod granted it the status of

Schuld gesteht [...] Schlussszene mehr als philosophische Essays uns in den Mittelpunkt jeder liebeglühenden Idee versetzt, die aus dem Wahrheit und ohne Eigensucht gefühlten Völkischen reine Menschlichkeit hervorspritzen lässt, wie diese göttliche Musik mir mehr über das Wesen der Nation und des wahren Nationalismus sagt als alle Theorie.” (Max Brod, "Jenufa Uebersetzung," in Sternenhimmel, 33, 22).

“Menschlichkeit, nicht Opernhaftigkeit, Menschlichkeit, nicht Nationalitatenhass!”. Ibidem, 35.

18 Ibidem, 41.

19 "Und dieses intime Volkshafte, niemals vergröberte drückt sich in jeder Modulation, jedem Motiv Janacek's aus”. (Max Brod, “Leos Janáček’s Jenufa,” in Sternenhimmel, 25.

20 „Der Realismus dieser eigenartige Methode könnte verdacht erwecken. Hier aber setzt der Genius aup. Nicht die Wortmelodie, sondern Eingebung, Umformung tritt in das Kunstwerk. „Ein Wortmotiv“ sagt Janacek, „atmet in eigener Wärme, glänzt in Eigenlicht. Ich schleife seinen melodischen Kanten, seinen rhytmischen Flächen - wie die Edelstein. Aus diesem Element leitet er weiter die Harmonie ab“. (Max Brod, “Leoš Janaček's Jenufa,” in Sternenhimmel, 25. 
an absolute music due to the fact that the composer was versed in classical techniques i.e. reprise, variation, gradation, augmentation and subtle changes of the rhythm. ${ }^{21}$

Later on, in his article One More Word about Jenufa (Noch ein Wort zur Jenufa), ${ }^{22}$ Brod once again criticized the attempts to label Janáček as naturalist or impressionist. In his opinion, the composer was a "stylist of melody" (Stilkunstler der Melodie) because instead of "frosting" naturalistic motifs he sketched the melodies of speech from nature. The latter process was ingeniously compared by Brod to the early stage of teaching drawing i.e. sketching nudes (Aktzeichnen) - in other words, Janáček would have started his musical way as a "craftsman collecting the archive of melodic motifs" and the final result would have been a miracle. In the same article Brod placed Janáček's music somewhere between the opera universe by Verdi and by Wagner, because the melodies of his arias are declamatory and his recitatives full of pithy melodic fragments. ${ }^{23}$

There is an obvious analogy between Janáček's comments regarding his own music and Brod's remarks. The more active party in that couple was very probably Brod. The certain proof of his influence on Janáček's self-reflection is how much the composer stresses the impact of the authenticity of the art on the gestation of his mind - the authenticity stemmed, of course, from close relationship between the artist and his geographical-natural background. In his late paper entitled The Creation (Das Schaffen) Janáček wrote:

I particularly appreciate the warmth I feel in my mind and blood whenever I sense that miracle of nature which surrounded me in my youth. All composers are children of their specific sensitivity, however, it has nothing to do with a science. An artist is rather a reservoir of certain predispositions. I am surprised with myriads of rhythms of the universe of colors, lights, sounds and dimensions. The eternally young rhythm of the eternally young nature is a mirror which brings life into all tones of my music. ${ }^{24}$

More interestingly, in a series of Brod's remembrance articles and in his monograph dedicated to Franz Kafka (published 1937), the author of Metamorphosis was provided with the same character traits as Janáček and made the advocate of similar artistic policy. The following excerpt from the above-mentioned monograph is a perfect example of blending the personalities of Janáček and Kafka by Brod:

\footnotetext{
Ibidem.

Sternenhimmel, 17-30.

Ibidem, 26.

24 „Gepriesen sich jene besondere, in Hirn und Blut ererbte Wärme des Empfindens für die Wunder der Natur, die meine Jugend umgaben! Das Empfinden macht den Komponisten; nich so sehr im wissenschaftlichen Sinn als im Schatz der Veranlagung. Ich staune über die tausend rhytmischen Erscheinungen der Welt des Lichtes, der Farbe, des Klanges und Raumes, und mein Ton verjüngt sich im ewig jungen Rhytmus der ewig jungen Natur.“ Leoš Janáček, Musik des Lebenp. Skizzen, Feuilletons, Studien, trans. Jan Gruna (Leipzig: Reclam, 1979), 68.
} 
In the course of time all that [Kafka] said or wrote has begun to reflect - more and more naturally, without constraint - his specific way of seeing things, the way that was affirmative, full of patience and tolerant irony for the foolishness of this world and therefore filled with painful humor; however, Kafka has never overlooked the "indestructible" core of truth and so never become blasé or cynical ${ }^{25}[\ldots]$ He has never told: "Look, it is the right way" or even "It is also a way". He has just stridden forward - being fully absorbed with his way, without seeking philosophical terms (his marvelous diaries prove that he thought only with images), and being busy solely with the avid observation of details unveiled to him by the changeable perspectives of the way ${ }^{26}[\ldots]$.

Brod's monograph of Kafka may be helpful if one wants to find the sources of his earlier enthusiasm for Mahler, for the first time expressed in the article Jewish Folk Melodies (Jüdische Volskmelodien) that was published in 1916 in Der Jude, a Zionistic periodical edited by Martin Buber, and then (1920) reprinted under the title of Jewish Melodies of Gustaw Mahler (Gustav Mahler's jüdische Melodien) in the Musikblätter des Anbruch, an interwar Viennese magazine dedicated to the new music. ${ }^{27}$

Brod's approach to the riddle of Mahler is barely different to his later treatment of Janáček - he once again takes the readers to a separate universe. This time it is a world of Galician Chasidim who settled in Prague. Brod plays a role of mystagogue who uncovers its wonders: shows the readers a synagogue where a rabbi accompanied by a choir of voices -alternatively the low, masculine and the high, boyish ones - chants "holy" Chassidic melodies. That mystical choir unexpectedly turns out to resemble something "deeply Jewish" (tief jüdische) i.e. the music of Mahler, and Brod enumerates the features responsible for that resemblance. According to the critic, one of them is frequent use of march rhythms by Mahler. Contrary to other critics, Brod derives them neither from the influence of military music, well known to Mahler, nor from German folksongs. Instead, he reads "eternal boom - tra - ra" (ewiges Bum - tra - ra) into the rhythm of Chassidic folksongs, which, in his opinion, can be seen in subtle rhythmic nuances, in the very characteristic alternation between major and minor systems in melismas, as well as in the "acceleration" to the proper pace through the repetition of the same sound several times; hardly recognizable for non-Jewish ear, it would nonetheless prove the Jewish roots of the genius of Mahler (in the spirituality of his symphonies march rhythm would stand for the souls on their way to God). Apart from that, Brod found "Jewish soul" in Mahler's music analyzing - in the manner described above - the composer's songs, especially the song cycle entitled Des Knaben Wunderhorn. All features of that musical works that seemed to be incoherent, styleless, odd or even cynical to the German ear, Brod ascribed to the fact that they are echoes of the "tone of the heart" (Herzensgrundton) shared by all artists of Jewish origin. In the conclusion of his article Brod attributes the Jewish inspirations by

25 Max Brod, Franz Kafka, 94.

26

Ibidem, 75.

27 Max Brod, „Jüdische Volksmelodien,“ Der Jude, No. 5 (1916): 344; idem, „Gustav Mahlers Jüdische Melodien,“ Musikblätter des Anbruch, No. 10 (1920): 378-379. 
Mahler to the spirit of the Orient, which is not at all surprising because it allows him for interpreting such works as The Earth Song by means of the same critical method.

In his book Jewishness in Music (Das Judentum in der Musik, 1926) Hans Berl stressed the importance of Brod as a discoverer of Jewish substratum (jüdische Substanz) in Mahler's music. Berl borrowed many Brod's concepts and included them in his own conception regarding the position of Jewish music within the European culture. Among those concepts the most important was the belief in an ahistorical character of the mentioned substratum in art. ${ }^{28}$ Berl shared with Brod also the conviction that the rhythm has been primordial source of music as such, and both believed in linearism i.e. primary role of melody in all music "engrafted" with Jewish spirit. Therefore, they both considered Mahler and Schönberg as composers of the future, able to oppose Wagner's musical style based on the predominance of harmony.

Brod altogether used to seek for everlasting and immutable (folk or national) elements in the musical style of various composers. In the Sternenhimmel, the previously mentioned volume of reviews, he described the music of several Czech composers using that framework. It is exactly the case of Brod's masterpiece of literary style and use of biblical metaphors - the sketch about the fantasy for violin by Josef Suk (Brod regarded that work as a proof of vitality of the Slavic music) $)^{29}$, and of the similar sketch concerning the music by Vítězslav Novák. ${ }^{30}$ Apart from that, in the same volume Brod commented on the opera The Distant Sound (Der ferne Klang) by Franz Schreker ${ }^{31}$ (making wide use of the notion of "naturalness"), and on the comic opera by Alexander Zemlinsky Fine Feathers Make Fine Birds (Kleider machen Leute) ${ }^{32}$. Yet the most important of Brod's reviews regarded the music of Arnold Schönberg i.e. his Gurre-Lieder ${ }^{33}$ and Pierrot lunaire. ${ }^{34}$ In the first of those reviews Brod made and attempt to derive the specificity of Schönberg's art from the "organic" coherence between his unflinching policy as a composer and as a theorist - he placed Schönberg's music within the post-Wagner tradition, but emphasized the fact that the composer had remained original and avoided epigonic imitation of Wagner's manner. Brod found the "poster music" by Richard Strauss an exemplification of such epigonism. In his opinion Schönberg took an inspiration from romantics (melodists!) - R. Schumann and $\mathrm{H}$. Wolf - thereby going beyond the Wagner's "hard" stylistics. Then Brod makes use of the same framework as in the case of Mahler: according to him Schönberg's music is soulful and almost divinized, eternity-heading (which, of course, stems from the traces of Jewish spirituality, absent in Wagner's music inspired by Germanic myths). In the review of the Pierrot lunaire Brod claims that Schönberg brought revolutionary (and very

28 Hans Berl, Das Judentum in der Musik (Stuttgart-Berlin-Leipzig: Dt. Verl.-Anst. 1926), 222.

Max Brod, „Ein Wort für Meister Josef Suk,“ in Sternenhimmel, 95-98.

Max Brod, „Über Vitezslav Novaks 'Sturm,'“ in Sternenhimmel, 99-101.

Max Brod, „Der ferne Klang,“ in Sternenhimmel, 110-111.

Ibidem, 103-107.

Max Brod, „A. Schönberg's 'Gurre-Lieder', in Sternenhimmel, 81-87.

34 Max Brod, „Pierrot lunaire. Liederzyklus von Arnold Schönberg,“ in Sternenhimmel, 90-94. 
desirable) changes to music returning to chamber arrangement and rejecting Wagner's monumental manner. Yet this time he does not analyze the religious background of Schönberg's music because he was not emotionally moved by the Pierrot lunaire: that composition, despite being an instrumental masterpiece, was too cold for him.

At the beginning of 1924 Brod took a regular job in the Prager Tagblatt, a Germanlanguage liberal-democratic daily newspaper. His duties consisted mainly of writing stage play reviews (including theatre plays, operettas and ballets - especially the premieres) and literary columns (the most interesting are his columns concerning the magical places). Apart from that, in the column entitled "Bühne und Kunst" (Stage and Art) he penned many musical reviews, signed either Max Brod or M.B., which regarded the current events from the Prague musical life. From time to time Brod used those events as a pretext for delivering his opinions with respect to music. They were also a great source of literary inspiration and pure fun, as Brod frequently played with his audience and beguiled it. Once, in order to encourage the readers to react for the reviews less blindly, he published two versions of the review of the premiere of the same operetta (one positive and one negative). He wrote also several reviews of his own literary works ${ }^{35}$ and of the operas which he provided with a German-language libretto. In his article concerning the opera Schwanda the Bagpiper by Jaromír Weinberger (published one day before its premiere in the German Theatre in Prague, 1929) Brod finally felt compelled to explain the reasons of such bias (he used exactly that word) ${ }^{36}$ Perhaps the funniest of his jokes was using an article by Schönberg advertizing a new musical periodical as a starting point for an innovative solmization, this time based on the first syllables of the surnames of the four contemporary German composers: Hi(ndemith) - Ho(nagger) - Hu(bay) - Há(ba). ${ }^{37}$

There is big difference between the earlier Brod's music criticism and his works published as a collaborator of the Prager Tagblatt. The main reviewer in that newspaper was Ernst Rychnowsky, a respected German-speaking Prague author (his monograph of Smetana has been highly valued since its publication).$^{38}$ Being an assistant reviewer, Brod decided to avoid crossing swords with him and so hardly ever assessed new compositions, including those by Janáček. Even in his rare reviews of opera plays he focused on the performance and set design; the assessment of the music itself remained Rychnowski's domain, especially in the case of world premieres. ${ }^{39}$ Subsequently, Brod found courage to

35 Max Brod, "Max Brods 'Prozess Buntelart'," Prager Tagblatt, October 12, 1924, 6.

36 Max Brod, "Schwanda der Dudelsackspfeiffer," Prager Tagblatt, April 14, 1929, 8.

37 Max Brod, "Arnold Schönbergs neue Notenschrift," Prager Tagblatt, January 31, 1925, 8.

38 Rychnowsky worked in the "Prager Tagblatt" until the end of the 1920s. His successor was Walter Seidl. Apart from them, the critical staff comprised several renowned authors e.g., Max Graf who later wrote an important book entitled Composer and Critic. In 1928 Graf moved to Vienna and a new critic was employed instead (using the alias Sthd).

39 E.g., Max Brod, "Ariadne auf Naxos," Prager Tagblatt, May 5, 1927, 7; idem, "Hindemiths 'Cardillac' (Aufführung)," Prager Tagblatt, March 15, 1927, 6; idem, "Die 'Meistersinger' Festvorstelung," Prager Tagblatt, January 7, 1928, 5; idem, "Die Entfühtrung aus dem Serail," Prager Tagblatt, February 
comment new operas as late as in the late 1920s with the emergence of some new musical works which referred to the folk/national idiom he accepted; such composers as de Falla, Weinberger, Weill or Křenek enlivened it with elements of jazz and popular music. In fact, Brod has always been keen on the art full of simplicity and naturalness and the opera was not an exception. Subsequently, he praised the performance of Gluck's Orpheus staged in the New German Theatre in 1933 exactly for those two features, ${ }^{40}$ and his review of Boris Godunov by Mussorgsky begins with the description of the composer as simple, clear and almost "courteous" (höflich) classic who has no pretenses to make a revolution in music, and is far from the madding noise of the modern compositions. ${ }^{41}$ In the article written in 1937 to commemorate the hundredth anniversary of Pushkin's death Brod once again referred to Mussorgsky and derived his musical genius from the influence of "deep darkness of religious memories" (tiefe Dunkel religiöser Erinnerungen) on his mind. ${ }^{42}$

It is not fortunate that in the period of his employment in the Prager Tagblatt Brod ceased to made comments on the Jewish element in music and seldom referred to the works by Mahler and Schönberg - albeit he considered the latter as a sage and founder of the new music (I will discuss that issue later). ${ }^{43}$ Regarding Mahler, in 1927 Brod told that his music had become classical and therefore it was pointless to give it more critical support. ${ }^{44}$ His incidental remarks on Mahler, penned on the occasion of various performances of Mahler's symphonies, contain the same repertoire of speculations about their background - spiritual, religious or Dionysian (after Nietzsche) ${ }^{45}$ However, in his review of the Mahler's Symphony no. 7 conducted by Alexander Zemlinsky (1927) the critic made an attempt to find a connection between the reviewed work and the romantic idea. In

17, 1928, 6; idem, “Ariadne auf Naxos," Prager Tagblatt, March 2, 1930, 8; idem, "Parsifal," Prager Tagblatt, April 29, 1930, 8.

40 Max Brod, "Glucks 'Orpheus'," Prager Tagblatt, January 18, 1933, 5.

${ }^{41}$ Max Brod, "Boris Godunov,” Prager Tagblatt, February 6, 1934, 8.

42 Max Brod, "Puschkin," Prager Tagblatt, January 29, 1937, 7.

43 Due to the political background in the interwar era as early as in the 1920s Prager Tagblatt has been devoided of such expressions as "an artist of Jewish origin" or "Jewish element in music". Victor Ullman, a Schönberg's apprentice and a very successful composer at that time - despite being born in Český Těšín (a part of the Austrian Silesia) - was consistently labeled as a "Sudeten German" (see e.g., cf. Ernst Rychnowsky, "Sudetendeutsche Komponisten," Prager Tagblatt, April 6, 1929, 7).

44 Max Brod, "Bruno Walter dirigiert," Prager Tagblatt, February 2, 1927, 6.

45 See e.g., Max Brod, "Viertes philharmonisches Konzert," Prager Tagblatt, March 9, 1929, 8 (see the comments on the performance of the 7th Symphony of Mahler by the Czech Philharmonic Orchestra); idem, “Zu Mahlers erstes Symphonie (dirigiert Zemlinsky)," Prager Tagblatt, December 1, 1931, 6, idem, "Gustav Mahlers 'Faust-Symphonie'," Prager Tagblatt, May 19, 1932, 5 (the article regards the 8th Symphony of Mahler and contains a valuable recapitulation of the issues connected with all his symphonies). 
the article regarding the Symphony no. 8 Brod ingeniously found the conjecture between Mahler's music and Goethe's Faust, too. ${ }^{46}$

Schönberg's works, in turn, have been performed less frequently in Prague since the composer moved to Berlin in 1926. In spite of that, for Brod they remained the touchstone, as Janáček and Mahler's music. The critic was consistent in focusing on those of new artists whose compositions - in his opinion - somehow referred to romantic idea or contained religious substratum or "the voice of nature" i.e. folk or dance elements. All those features allowed Brod for making wide use of his conceptual framework developed during the analyzes of the music by Janáček, Mahler and Schönberg. Therefore, he paid much attention to the opera Schwanda the Bagpiper by Weinberger and called that work a perfect example of the modern comic opera making the audience smile and not laugh by means of "its humor and natural warmth of its melody" (natürliche Wärme der Melodie und Humor). ${ }^{47}$

Brod enjoyed also the Cantata of the Last Things of Man by Ladislav Vycpálek whose world premiere took place in the spring of 1925 in Prague at the International Music Festival (Internationales Musikfest). According to Brod, that work comprised quasi-Mahler's pantheistic elements (religiöser Naturstimmung). He was particularly impressed by the crescendo in the finale - allegedly reflecting the existence of God - and praised Vycpálek for "brave atonality" (kühne Atonalität) resembling Schönberg's music. ${ }^{48}$ Analogically, he found "romantic irony" and "imitations of folksongs" (VolksliedImitation) - in his though typical of Mahler's manner - in the string quartet by Hans Krása. The review of that quartet, published in 1927, pertains also to the string quartet by Viktor Ullmann which is an atonal, technically challenging piece: Brod praised the composer for using the rhythm of waltz as "reaching the heart". ${ }^{49}$ In Ullman's Concerto for Orchestra Brod appreciated its formal and instrumental intricacy (Problembestaltung), but the main source of his enthusiasm were the march rhythms able to disentangle the structural density of the entire work and to bring joyful feelings. ${ }^{50}$ All these examples should help us understand why Brod hold Bartók and Danish composer Carl Nielsen in such high esteem: whereas the former incorporated folksongs into his music (as Janáček

46 Max Brod, "Philharmonisches Konzert (Zemlinsky dirigiert Mahlers VII. Symphonie)," Prager Tagblatt, May 15, 1927, 9; idem, “Gustav Mahlers 'Faust-Symphonie',” Prager Tagblatt, May 19, 1932, 5 (the article regards the 8th Symphony of Mahler and contains a valuable recapitulation of the issues connected with all his symphonies).

Max Brod, "Schwanda, der Dudelsakcspfeiffer," Prager Tagblatt, December 16, 1928, 7.

Max Brod, "Vokalkonzert," Prager Tagblatt, May 19, 1925, 7.

Max Brod, “Abend Prager Komponisten,” Prager Tagblatt, May 20, 1926, 9.

Max Brod, "Viertes philharmonisches Konzert," Prager Tagblatt, March 9, 1929, 8. (Cf. footnote 39 - the reference is to the same concert performed by the Czech Philharmonic Orchestra conducted by Steinberg.) 
did),${ }^{51}$ the latter provided the chamber music with a Nordic aura and with almost religious concentration stemming from the heritage of Bach and Brahms. ${ }^{52}$ Brod was also an admirer of the cantata Die Lebenden den Toten by Vomáčka (he analyzed that composition with regard to the convincing way of delivering religious texts). ${ }^{53}$

In 1924 Igor Stravinsky visited Prague. His visit echoed in the local musical circles but his concert turned out to be too challenging for the most of the audience - so many people left before its end that Brod felt himself forced to write the first of the series of his philippics against the Prague melomans. It was a fierce article entitled "Once Again You Have Completely Disgraced Yourself!” („Du hast dich wieder bis auf die Knochen blamiert”!). In that review Brod zealously preached to all doubters that one day Prague would accept Stravinsky as it had accepted Schönberg, ${ }^{54}$ one more time expressing his critical stance of uncompromising believer in the final victory of the new music he admired.

On the other hand, Brod sometimes went too far in the above-mentioned admiration. His paper on Smetana - an aftermath of the concert performed in the National Theatre in Prague (Národni divadlo) to commemorate the 40th anniversary of Smetana's death - is a recklessly odd attempt to render that Czech composer as a Schönberg's predecessor (sic!). Brod based his wild conjecture on the alleged presence of the analogical traits and solutions in the musical works by Smetana and Schönberg (e.g. "satanic (sic!) dissonances"). "Who then emerges from that piece? [Aus meinen Leben quartet by Smetana - M.J.] A <jolly> man?” - with that rhetorical question Brod summarized his quite twisted description of Smetana. ${ }^{55}$

It is true that in the course of time Brod has gained more professional experience and his opinions regarding the modern music have become more objective. Yet as a music critic he has never rejected the idea that valuable musical works are much more than "a cold exercise of the mind" (kaltes Verstandübung) - they must reflect the personality and comprise ideological and expressive content in order to bring life into an element of the culture. ${ }^{56}$ As a result, he has striven for finding such features at all costs. e.g., he "discovered" lyrical (emotional) and romantic traces (technically inherited from BrahmsReger) in the viola concerto by Hindemith ${ }^{57}$ under the "layers of machinery".

51 Max Brod, "Konzert Francis Aranyi," Prager Tagblatt, February 16, 1927, 6. The remark is on the performance of the Bartók's Allegro barbaro.

52 Max Brod, "Knut Hamsun in Musik gesetzt," Prager Tagblatt, October 21, 1927, 6.

53 Max Brod, “Uraufführungen in Konzertsaal," Prager Tagblatt, February 26, 1929, 6.

54 Max Brod, “Prager Publikum!,” Prager Tagblatt, November 16, 1924, 6.

55 Max Brod, “Aus dem tschechischen Künstleben,” Prager Tagblatt, May 14, 1924, 7.

56 Brod several times used the notion of "vivid cultural element" (lebendigers Kulturelement), most notably in 1928 in his reviews concerning one-act plays Life is Short (La vida breve) by de Falla and The Tsar Has his Photograph Taken' (Der Zar lässt sich photographieren) by Kurt Weill. Cf. Max Brod, “Zwei moderne kleine Oper.” Prager Tagblatt, November 11, 1928, 8.

57 Max Brod, "Hindemith spielt auf," Prager Tagblatt, November 3, 1929, 8. 
According to the contemporary academic classifications of genres and trends in the music of the 20th century, Brod is a neoclassicist with a positive attitude to all types of stylization including folklore, because he openly admired such composers as Arthur Honegger, Francis Poulenc, Albert Roussel, Hans Krása or Bohuslav Martinů ${ }^{58}$ and wrote enthusiastic sketch on Ravel's Bolero (Brod regarded that work as a masterpiece of natural simplicity whose musical language is so elementary that almost "a mystery"). ${ }^{59}$ However, he accepted those avant-garde innovations to music that somehow referred to jazz, popular music or the classical genres and techniques - for Brod's they all contributed to modern folk music, which is reflected in his articles. Perhaps the best exemplifications of that peculiar opinion are Brod's reviews of the two annual concerts dedicated to German composers from Prague. Those concerts were organized by the periodical Auftakt in 1929 and involved the works of such composers as Fidelio Finke, Victor Ullman, Ernst Křenek, Carl Wiener and Erwin Schulhoff ${ }^{60}$ - the last one was particularly praised by Brod. ${ }^{61}$ I would also stress the fact that in his review on the Prokofiev's performance in The Czech Philharmonic House (1932) Brod compared Stravinsky and Prokofiev only to regard the former as "more courageous" (kühnere) "summoner of all tradition" ([derjenige] der Alle Tradition bricht). On the other hand, Brod esteemed Prokofiev's "deeply personal” (allerpersönlich) and often "mysterious" (geheimnisvoll) creativity. ${ }^{62}$ In the 1930s Brod often made similar comments on the music by various Czech composers, especially on Vítězslav Novák whose Herbst-Symphonie he praised for joining the modern technique with the romantic content. ${ }^{63}$ Even Alois Hába was granted absolution, despite the fact that his music was impenitently modern. In his case Brod found an excuse that Hába did not compose ${ }^{64}$ "as mathematicians do" but with a visible care for melody and emotional expression. ${ }^{65}$ All the above mentioned examples well reflect the musical hierarchy from Brod's perspective.

58 E.g. Max Brod, “Bühne und Kunst. Konzerte,” Prager Tagblatt, April 22, 1931, 6 (the article regards the works by, among others, Debussy, Honegger, Roussel and Martinu; idem, „Die Erde is des Herrn," Prager Tagblatt, March 11, 1932, 6 (the article regards the oratory by Hans Krása); idem, "Uraufführung," Pager Tagblatt, March 18, 1932, 5 (the article regards e.g. the double sonata by F. Poulenc).

59 Max Brod, "Bolero," Prager Tagblatt, May 25, 1920, 6.

60 Max Brod, “Auftakt-Konzert,” Prager Tagblatt, March 10, 1929, 7; idem, “Auftakt-Konzert,” Prager Tagblatt, November 19, 1929, 7.

61 Max Brod, "Max Brod, Erwin Schulhoffs Mondpantomime," Prager Tagblatt, April 8, 1932, 6.

62 Max Brod, "Konzert Prokofiev," Prager Tagblatt, January 13, 1932, 5.

${ }_{63}$ Max Brod, “Vitězslav Novák 'Herbst-Symphonie’," Prager Tagblatt, December 20, 1934, 6.

64 I am referring to a quarter-tone method of composition.

${ }_{65}$ Max Brod, “Orchesterkonzert," Prager Tagblatt, April 10, 1936, 6. Przedmiotem oceny była uwertura do opery Háby Nowa ziemia (Neue Erde). 
Since the early 1930s Brod has started using new and crucial term: kitsch. The first work he labeled as kitsch was the opera The Dead Eyes (Die toten Augen) by Eugen d'Albert whom he disliked. Brod reproached the composer with using "secondhand effects" ${ }^{66}$ The notion of kitsch was adopted by the critic during his contacts with the intellectual circles connected with the Viennese periodical Musikblätter des Anbruch (e.g., Theodor Wiesengrund Adorno) that fiercely opposed all trivial art considering it as a "fetish" of the petty-bourgeois consumer culture. Apart from kitsch, around the same time Brod has begun using other derogatory terms with respect to the musical trends he disliked. One of them was radical musical avant-garde. Such remarks as "sharp, wild manner" (scharfe wilde Manier) or "crude fighting methods [of the supporters - M. J.] of the modern music" ("rude Kampfmethoden der modernen Musik") reflect cooler and cooler attitude of Brod towards the radical musical experiments and are often contrasted with the new compositions somehow rooted in a tradition e.g., neoclassical ballets by Vítězslav Novák. ${ }^{67}$ In Brod's repertoire of critical invectives "snobbism" ${ }^{68}$ has played a prominent role, too. It has been a flexible epithet to make caustic remarks on modern manner in concert music and on jazz music, the latter being more and more popular in Prague in the beginning of the third decade of the 20th century. For instance, Brod was disgusted by the performance of the Jack Hylton Band - an American jazz orchestra very popular in Prague in the interwar era. He ironically suggested that that "snobbish" band did not perform but rather manufactured music whereas its audience consisted of "businesslike people" (sachliche Menschen); it is quite easy to guess the origins of those Brod's punch lines. ${ }^{69}$

In his somewhat earlier review of the works by Erwin Schulhoff and Oswald Chlubna (the last one, a Janáček's apprentice, is hardly known today) Brod compared the Moravian land to "the island upon the sea of leveling internationality" (nivelierende Internationalität) ${ }^{70}$ because he considered national schools as a proper remedy for "the cold modernism" "11 using unified musical language. Brod highly valued the national music for its communicativeness and ability to influence many people due to the retention of the traditional elements. "In the case of all modern operas one is vexed with one question: what an ordinary man can understand of it? Can he remember any of this?" - it is a gist of Brod's review of the new opera by Hans Krása (1933). ${ }^{72}$

${ }_{66}$ Max Brod, "Die toten Augen," Prager Tagblatt, February 5, 1930, 8.

67 Max Brod, “Zwei Balette von Novák,” Prager Tagblatt, March 11, 1930, 7. The article regards two ballets: Signorina Gioventina and Nikotina.

68 Max Brod, "Moderne Kammermusik," Prager Tagblatt, March 11, 1931, 4.

69 Max Brod, “Jack Hylton fabriziert Musik,” Prager Tagblatt, November 27, 1931, 7.

70 Max Brod, "Tschechische Philharmonie," Prager Tagblatt, March 21, 1930, 6.

71 Max Brod, "Erstes Novák-Konzert,” Prager Tagblatt, November 20, 1930, 6.

72 „Bei modernen Opern wird man immer wieder gefragt: versteht der Laie etwas davon? Bleibt eine Melodie im Ohr haften?" Max Brod, “Krása 'Verlobung im Traum'," Prager Tagblatt, May 20, 1930, 5. Of course that opera met Brod's requirements with regard to the communicativeness of musical language. 
Brod had a high regard for the national music because of the obvious ideological reasons. He was a Zionist and democrat (as the whole editorial staff of the Prager Tagblatt). Therefore, he paid close and kind attention to all the deeds of the Prague musical community. Aside from the regular reviews of the performances played and staged by the Czech Philharmonic he commemorated the 50th anniversary of the Czech National Theatre in Prague, ${ }^{73}$ wrote the review of the performance of Libuše by Smetana (staged on the same occasion) ${ }^{74}$ Another important paper by Brod regarded the concert dedicated to Czech and German composers that was performed in 1933 in the theater D34 thanks to the efforts of its owner Emil František Burian, a playwright associated with the communism. ${ }^{75}$ Among Brod's later articles about Smetana one should mention the review of the first premiere of Smetana's opera Two Widows staged in the Czech language in the National Theatre in 1934: Brod summarized that review with an almost Buber's remark on the "holy" (heilig) content of the work.

Brod's stance on some artists sympathizing with communism (e.g., Weill or Burian) was positive, although he has never openly referred to their political views and used to describe their works through his own critical filter. In other words, he was interested in finding in those works the naturalness and simplicity enabling them for good social interaction. It is exactly the case of the play Lidovy Král by Burian containing the stylized versions of the secular songs from the Middle Ages. ${ }^{76}$ Shortly before the Second World War Brod breached one of the biggest taboos for a professional music critic - he has become a supporter of popular musical hits and started to praise them for their authenticity. One of his last columns published in the Prager Tagblatt is a story of musical hits in the interwar Prague: for Brod the particular songs symbolized the particular years in his life. ${ }^{77}$

Despite his growing aversion to atonality and too radical musical experiments (shared with the entire editorial staff of the Prager Tagblatt) Brod has never changed his opinion about the importance of Schönberg's contribution to music. In the autumn 1930 Schönberg visited Prague and gave a lecture concerning the idea of the new music. ${ }^{78}$ In response to that lecture Brod penned a review in which he once again stressed that in his way to the truth Schönberg was accompanied by the faith and love. ${ }^{79}$ However, he remained skeptical with respect to the practical application of the Schönberg's theory: for Brod many works by Schönberg, Webern and Berg belonged to the category of intellectual „abstraction”. Berg's Chamber Concerto (1932) pushed him to express an opinion that dodecaphonic music would never become a cornerstone of the music of the future, sharing

\footnotetext{
Max Brod, “Fünfzig Jahre Tschechisches Nationaltheater," Prager Tagblatt, November 12, 1933, 8.

Max Brod, "Festvorstellung in der Nationaltheater (Libuše)," Prager Tagblatt, November 21, 1933, 8.

Max Brod, "Voiceband - Fürnberg - Süsskind,” Prager Tagblatt, November 17, 1933, 5.

Max Brod, “Grosse Historie bei E. F. Burian,” Prager Tagblatt, October 26, 1938, 5.

77 Max Brod, “Jahresringe der Musik," Prager Tagblatt, October 30, 1938, 3.

"Moderne Musik," Prager Tagblatt, October 22, 1930.

79 Max Brod, “Arnold Schönbertg doziert," Prager Tagblatt, October 23, 1930, 6.
} 
the fate of the older Wagner's theory. ${ }^{80}$ Brod was also disappointed with Hindemith's compositions and called his Concerto for viola d'amore, performed in Prague in the first months of 1931, "unromantic" (unromantisch) and "disputable" - because of the almost vexatious fabric of that piece. ${ }^{81}$

In the 1920s and 1930s Brod quite frequently referred to Janáček. The performances of his works in Prague were good pretext for such comments. ${ }^{82}$ Besides, Brod published a series of articles dedicated to Janáček in the Prager Tagblatt. One of them concerned the 70th anniversary of composer's birth which ended in a scandal because Janáček was accidentally not invited..$^{83}$ The series comprises also an enthusiastic review of the Berliner premiere of Jenufa, ${ }^{84}$ the article entitled Jenufa-Reminiszenzen, ${ }^{85}$ and an anniversary biographical paper containing some supplementary glosses to Brod's description of the music by Janáček. Among others he analyzes "the tectonic style" (tektonische Stilkunst) of the composer, ${ }^{86}$ which is a certain proof that he was acquainted with the Angewandte Musikaesthetik by Mersmann that was published at that time. Some other Brod's literary works dedicated to Janáček were also published (partially for the first time, partially as reprints) in the Viennese periodical Musikblätter des Anbruch. ${ }^{87}$

As a professional reviewer Brod regularly commented on operettas and ballets. Those comments are valuable source of his reflections in regard to music. Generally, in the above mentioned musical genres he esteemed simplicity, naturalness and positive attitude towards folklore i.e. making bold use of folk melodies or dance rhythms. In his text about Thousand and One Nights (Tausend und eine Nacht) by Johann Strauss Brod drew a distinction between the classical operetta and the modern "hit operetta" (Schlageroperette) intended to indulge bourgeois tastes. According to Brod, the presence of waltz in the old operetta stems from "its immediate bonds with the folklife" 88 because waltz is a descendant of the folk dance called lendler; modern operetta is devoided of such bonds. Brod

80 Max Brod, "Kunst. Alban Bergs Kammerkonzert," Prager Tagblatt, February 3, $1932,7$.

81 Max Brod, “III Philharmonisches Konzert," Prager Tagblatt, January 23, 1931, 8.

82 Np. Max Brod, "Moderne Kammermusik [the review of the wing quintet that performed a juvenile suite of Janáček (entitled 'Jugend')]," Prager Tagblatt, March 11, 1931, 4.

83 Max Brod, "Bühne und Kunst," Prager Tagblatt, January 19, 1924, 5.

84 Max Brod, “Janáček's 'Jenufa' an der Berliner Staatsoper," Prager Tagblatt, March 16, 1924, 2.

85 Max Brod, “Leoš Janáček - 70 Jahre alt,” Prager Tagblatt, July 30, 1924, 7.

86 Max Brod, “Jenufa-Reminiszenzen," Prager Tagblatt, October 27, 1926, 6; “Leoš Janáček - 70 Jahre alt,” Prager Tagblatt, July 30, 1924, 7.

87 Max Brod, “Leos Janacek’s Klavierstücke,” Musikblätter des Anbruch, 1924, 12; “Leos Janacek's Persöhnlichkeit," Musikblätter des Anbruch, 1924, 237; "Jenufa-Reminiszenzen," Musikblätter des Anbruch 1926, (special issue "Oper”); "Errinerung an Leoš Janáček,” Musikblätter des Anbruch, 1928, 233.

88 „Vorzug der älteren Operette: Sie hat eine unmittelbare Beziehung zum Volksleben”. Max Brod, "Alte Operette," Prager Tagblatt, March 4, 1924, 3. Cf. also Max Brod, "Edle Vorkriegs-Operette (zur Neueinstudierung des <Opernbal〉)," Prager Tagblatt, December 20, 1924, 6. 
depicted the waltz as "music closest to the nature" ("stärkste Naturnahe") many times, for instance in his review of the ballet evening in the Vienna opera house (Johann Strauss music was a must on such occasion), ${ }^{89}$ and in the article commemorating the performance by Anna Pavlova whose dances to Russian music contained - at least for Brod - "some Dionysian elements" consisting in the dependence on "elementary folk art" (Elementare Volkskunst)" ${ }^{90}$ Another example is his review of the evening by Diaghilev and his Ballets Russes where the dance performance to Borodin's Polovian Dances "unshackled the dark orgiastic powers of the folklore" (dunkle orgiastische Kräfte des Volkstums") ${ }^{91}$ as the dancers maintained their bonds with the spirit of the Russian culture. After the premiere of The Land of Smiles by Lehár Brod scrupulously analyzed how much "natural" is its oriental stylization. ${ }^{92}$

Brod wrote relatively few articles concerning classical music. Most of them pertain to the genre he preferred i.e. monumental vocal-instrumental works to secular or sacred texts. ${ }^{93}$ Brod's interpretations of Mozart or Bruckner are then detailed analyzes of the relationship between the text and music conducted in order to assess if it leads to the proper mood or form of expression (the critic used to call it the issue of internal truth of the musical piece).

Apart from reviewing various composers and compositions, Brod assessed many soloists and conductors. In that respect, he was an avid observer and his remarks on the appearance, behavior and personality of the particular musicians are vivid. He preferred, of course, charismatic artists able to enchant the audience and conjure up the mood, however, not by means of the learned tricks but rather with the pure concentration of the spiritual powers similar to the mystical trance (Brod used such comparison) ${ }^{94}$ His descriptions of the conductors and virtuosos at play often refer to the images of "suspension between the heaven and earth" or "opening the gates of the higher world". In the same context Brod sometimes openly told about the piety that elevates the souls of the listeners: metaphysical and mutual joy depicted in that manner is typical of the Chasidim.

Brod was no doubt able to objectively assess the style of performance (especially when it came to piano works as he played the piano on his own), but he favored the "emotional" (in the case of classical-romantic repertoire) or "picturesque" (in the case

\footnotetext{
Max Brod, “Das Wiener Staatsopernballett in Prag," Prager Tagblatt, November 28, 1926, 9.

Max Brod, "Anna Pavlowa," Prager Tagblatt, February 16, 1927, 6.

91 Max Brod, "Das Russische Ballett in Prag," Prager Tagblatt, November 22, 1927, 6.

92 Max Brod, "Lehar-Premiere," Prager Tagblatt, February 25, 1930, 7.

93 Max Brod, "Bruckners Messe F-Moll," Prager Tagblatt, January 24, 1929, 6; idem, "Mozarts Requiem," Prager Tagblatt, March 19, 1929, 8.

94 Max Brod, "Huberman-Konzert," Prager Tagblatt, November 19, 1927, 7; idem, "Konzert Bruno Walter," Prager Tagblatt, March 6, 1928, 7; idem, “Konzert-Rachmaninoff," Prager Tagblatt, December 4, 1930, 6 (the article contain another comparison between the world of music and the magical universe of the romantic literature i.e. Jean Paul and E.T.A. Hoffmann). Max Brod, “Zwei Liederabende," Prager Tagblatt, March 27, 1928, 6.
} 
of impressionist repertoire) ones. ${ }^{95}$ Brod praised an English madrigal ensemble ${ }^{96}$ as well as Lore Korueli, a soloist singer who in the spring 1928 performed some long-forgotten songs from the 18th century - in both cases he underscored the professionalism and expressiveness of the artists. ${ }^{97}$

On the other hand, Brod opposed the magic of names and was merciless whenever a famous virtuoso gave a lame performance which raised undeserved applause. He severely criticized the Prague audience for "clapping their hands with delight after [Eugen d'Albert] deformed so many of the fine works of the masters" ${ }^{98}$ Brod's unbiased critical attitude towards the performance of music is visible in his reviews. The exemplifications of that are his reflections on a perfect opera conductor (written on the occasion of Georg Szell's visit to Prague before his employment in the German Theater) ${ }^{99}$ or the remarks on Wilhelm Furtwängler. Reviewing the latter, Brod made a distinction between the "aesthetic" ("waving their hands as a magician") and "effective" (coping with the orchestra) conductors. ${ }^{100} \mathrm{He}$ also penned a review of Arturo Toscanini's performance in Prague. ${ }^{101}$

In the 1920s Brod postponed his attempts to find Jewish elements in music, most probably due to the growing anti-Semitism in Europe. However, he has never lost his interest in Jewish music as such. For instance, in 1928 the Jewish troupe Habimah from Moscow performed in Prague putting up Dybbuk, The Golem and The Eternal Jew. These plays were well-known and popular among the Central-European audience, but the Habimah's performance was modern and inspired with the methods by Konstantin Stanislavsky. Therefore, the musical setting was rich and involved genuine Jewish songs and dances accompanied by the orchestra. The plot included the reconstructions of religious rituals and ceremonies of the Carpathian Jews e.g., the wedding. Brod was, naturally, enraptured with the quality and scope of the reconstruction of the folk music that allowed for rendering its form and the very specific passionate subtones. He call it "an absolute natural product" (absolut Naturwar) and stressed the fact that Habimah used the Sprechstimme,

95 Max Brod, "Konzert Ignaz Friedman," Prager Tagblatt, October 10, 1926, 10; idem, Max Brod, "Klavierabend Alice Herz," Prager Tagblatt, March 7, 1928, 6, idem, "Konzert Gieseking," Prager Tagblatt, February 7, 1930, 7; idem, "Konzert-Rachmaninoff," Prager Tagblatt, December 4, 1930 , 6; idem, "Klavier mit Sordine [the review of the recital of Walter Gieseking]," Prager Tagblatt, February 13, 1931, 6, idem, "Konzert Friedmans," Prager Tagblatt, February 27, 1931, 6; idem, "Konzert Horowitz," Prager Tagblatt, October 11, 1931, 7; idem, "Konzert Huberman," Prager Tagblatt, November 25, 1931, 7.

96 Max Brod, "Madrigal-Abend," Prager Tagblatt, April 10, 1929, 6.

${ }_{97}$ Max Brod, "Zwei Liederabende," Prager Tagblatt, March 27, 1928, 6.

98 "[das Publikum] applaudierte begeistert den Deformationen erhabener Meisterwerke“. Max Brod, “Konzert Eugen d'Albert," Prager Tagblatt, March 4, 1926, 6.

99 Max Brod, “Gastdirigent Georg Szell," Prager Tagblatt, May 14, 1929, 8.

100 Max Brod, "Konzert Furtwängler," Prager Tagblatt, April 23, 1931, 6.

101 Max Brod, “En Genie der Genauigkeit," Prager Tagblatt, May 25, 1930, 6. 
Schönberg's modern technique of singing. ${ }^{102}$ Brod's perception of the artists of Jewish origin e.g., Krása, Zemlinsky or Huberman was very specific and based on looking in their works and personalities those features he considered deeply Jewish - religiousness, piety and ability to be delighted with God's world and to treat the music as a message from the "eternity".

In the light of all the mentioned examples Brod seems to be a typical subjective critic who in the first place remains a writer and subsequently uses his artistic self as a highly personal filter for the gathered information and inspiration. Brod received a professional musical education and knew the arcana of the composition and performance very well, yet his reviews and remarks were deliberately biased or - to be more precise - intended to show his own interests and opinions regarding the art. Brod's musical criticism is deeply embedded in the great discourses of the interwar era and intertwines the purely musical discussion with the existential, sociological and anthropological issues such as the condition of the contemporary man, the tradition and future of the Europe and entire world, or Zionism. Being one of German-speaking supporters of the new music, Brod considered the changes taking place within it as a necessary and inevitable process - just like Adorno and other intellectualists connected with the Musikblätter des Anbruch. However, in the course of time he has become a "moderate conservative", which was hardly strange (even in German-speaking circles). As such, he couldn't abstain from taking his stance in the fundamental discussion on the hierarchy of the trends in the modern music, which included such issues as the boundaries of musical experiment, the mutual relationship between the avant-garde and conservatism, between the nationality and "internationalism" and between the instrumental music and opera. In that discussion Brod opposed to those who wanted to cut the bonds between the new music and the tradition. His arguments in favor of the return to "normality" (in the last years of his employment in the Prager Tagblatt Brod used to give some examples of the young German composers as a proof that such process had already been completed) in the 1930s were beyond the standard critical remarks. On the other hand, in his comments Brod frequently used the words that had been expelled from the professional music criticism long before his birth, e.g., "Wunder" (miracle, wonder), "holiness" or "eternity". This time, they were intended to direct the attention of the readers to the metaphysical superstructure of the art. Brod used to describe Mahler, Schönberg, Kafka and those artists he considered as their conscious successors in a very specific way - he has made no distinction between the value of the art and its moral or religious significance. Brod was first fascinated with Martin Buber and his teachings. As a result, he started to show the "human nature" of his musical or literary idols as something stemming from the strength of their personality and able to open the metaphysical horizon of the art by virtue of "simple" means. The word "simple" should be understood according to the Buber's story The Wise and the Simple. Its point tells the reader that sometimes one should open to the bless of the silliness. Max Brod certainly

102 Max Brod, “Die Moskauer 'Habimah'," Prager Tagblatt, February 25, 1928, 7; idem, “Der Golem,” Prager Tagblatt, February 26, 1928, 7. 
took that path. Doing this, he turned out to be brave enough to cross the boundaries of the traditional musical criticism.

Translation: Piotr Plichta

\title{
Max Brod as a Music Critic
}

\begin{abstract}
The article is devoted to the presentation and interpretation of critical-musical works of Max Brod, Czech-born German-Israeli writer, composer and librettist, best known as a monographer of Franz Kafka. On the basis of the press articles (published, inter alia, in German-speaking daily "Prager Tagblatt"), the author analyzes and systematizes Brod's views on musical art. Significantly, in the center of the critic's interest were found to be such composers as Leoš Janáček, Gustav Mahler and Arnold Schönberg. The press articles concerning Jewish music, more specifically - the "Jewish element" ("Jewishness") in music are discussed in detail. The author also attempts to answer whether the Zionist element of Max Brod's worldview could have affected his professional evaluation of musical pieces. At the end of the article critical-musical skills of Max Brod are subjected to the technical analysis, and his artistic views (particularly on Neue Musik) are placed in a wider context of the thought of the era.
\end{abstract}

\section{Max Brod jako hudební kritik}

\begin{abstract}
Abstrakt
Studie představuje a interpretuje hudebně kritické texty Maxe Broda; spisovatele německožidovského původu narozeného v Čechách, zároveň skladatele a libretisty, jenž proslul péčí o odkaz Franze Kafky. Na základě studia novinových článkủ (publikovaných mimo jiné v německojazyčném periodiku Prager Tagblatt) autor analyzuje a systematizuje Brodův náhled na hudební umění. V centru pozornosti Maxe Broda byli skladatelé jako Leoš Janáček, Gustav Mahler a Arnold Schönberg. Novinové články, jež se zabývají židovskou hudbou, respektive „židovskými elementy“ v hudbě, jsou pojednány zvláště podrobně. Autor věnuje pozornost rovněž otázce, do jaké míry mohl Brodův sionistický světonázor ovlivnit jeho kritickou reflexi hudebních děl. Závěr studie je věnován technické analýze hudebně kritických schopností Maxe Broda. Jeho vnímání umění (zvláště tzv. Nové hudby) je probíráno v širším historickém kontextu.
\end{abstract}




\section{Keywords}

Max Brod; Leoš Janáček; Gustav Mahler; Arnold Schönberg; Czech musical culture of the interwar period; Jewish music; Zionism in music; musical criticism.

\section{Klíčová slova}

Max Brod; Leoš Janáček; Gustav Mahler; Arnold Schönberg; česká hudební kultura v meziválné době; židovská hudba; sionismus v hudbě; hudební kritika. 